\title{
EFL Learners' Attitude toward Two Major English Varieties: From Perplexity to Prejudice
}

\author{
Rina Herlina \\ English Education Program, FKIP, Universitas Galuh \\ rinaherlina@gmail.com \\ Didih Faridah \\ English Education Program, FKIP, Universitas Galuh \\ didihfaridah@gmail.com
}

\begin{abstract}
For EFL learners, English language is a part of the main course to consume at school. However, some of them and even English teachers are not too familiar with 2 major English varieties (EV). They are American English (AE) \& British English (BE). So far, that issue doesn't bring up responsive concern, but some questions from EFL learners prompt such an inquiry. One of those questions is; which one of those EVs has more economical benefit for their future? In addition, frequent debate might occur among EFL learners about the correct version between kid or child, lorry or truck, taxy or cab, flat or apartment and many others. This chaotic mix-up is undeniable. Thus, this study investigates learners' attitude on both English varieties, $\mathrm{BE}$ and $\mathrm{AE}$, in terms of learners' prejudice and perplexity which are encountered in learning process. This survey embraced 50 university students to put forward their own perspectives on an open-ended questionnaire consisting of four questions. Next, all answers were grouped into three categories to be interpreted. The survey shows that $50 \%$ of students insist that AE is the most well-acceptable English across the globe that could contribute to their better future socially and economically, and the rest percentage shows various contradictive arguments. It is suggested that English teachers are supposed to consider the differences between $\mathrm{BE}$ and $\mathrm{AE}$ in designing teaching material to avoid $\mathrm{EFL}$ learners' perplexity and prejudice on both EVs.
\end{abstract}

Keywords: British English (BE); American English (AE); English variety (EV)

\section{A. Introduction}

Are you using British English or American English in teaching English? Which EV is more difficult between American English and British English? Which one is more important between American English and British English? Does International standard derive from English American or British English? Which one is more financially beneficial between AE and BE? What do you recommend? Those questions always come up in the middle of teaching learning activity. In the beginning, those questions didn't have my focus because it seems unimportant and silly. However, finally they succeeded to develop such a curiosity 
since I myself notice that $\mathrm{AE}$ and $\mathrm{BE}$ are different in some linguistic features including pronunciation, and vocabulary (Han, 2019). Thus, the perplexity goes to the EFL learners where some of them shared their experiences during being taught by their English teachers in high schools. They explained that their teachers claimed that /color/ is correct while /colour/ is not, /meter/ is correct rather than /metre/, 'taxy' is acceptable while 'cab' is not and the correct pronunciation of sound $/ t /$ in 'letter', 'water' and 'matter' must be clearly pronounced, whereas in American English, it is not clearly pronounced or $/ t /$ is hidden sound (Garrett 2010; Gomez, 2009; McKenzie, 2015; Dimitrova, 2010). This teachers' prejudice leads to be chaotic because they judge their learners' work incorrect and it effects learners' score. What they did is due to their unawareness of specific English variety like AE and BE. In addition, when typing words like /colour/ and /metre/ in computer, it automatically prompts red mark underlining those words which means the correct ones must be /color/ and Imeter/ (Roach, 2009; Bauer, 2010). It makes sense because Microsoft word was born in United States. Henderson et al. (2012) argued that "this undeniable chaotic perplexity occur when EFL learners are aware of this specific language variety which makes teachers and learners have different attitude of EV". Therefore, they want to make sure which EV is the best for their future and they learn English with confidence.

That English variety occurs among countries or regions that have the same language. Then the differences happen in terms of history, distance, culture, and even more weather (Ahmed, Abdullah \& Heng, 2013). The differences aspects contains pronunciation, vocabularies, grammar, expression and idioms. This will only happen if there is an interaction. Existing social interaction is due to talk activity among speakers and speech partners (Mesthrie, 2009). English varieties around the world have taken place for a long time. However, only American \& British English become a spotlight as well as destination for people who learn English language around the globe. EFL learners in Indonesia have their respective attitude on English variety. This forms such a perplexity because there hasn't been such a fixed parameter of what EV as standardized English is supposed to be learned (Fought, 2002).

The divergence between these two EVs is derived back in 17th century, when British arrived and established its colony in America, they began speak in English. Then trade, social and culture came up at the same time with the colony occupation (Hosseinzadeh, Kambuziya $\&$ Shariati, 2015). In the $18^{\text {th }}$ century, conflict burst out. This triggered the differences and interactions among them which divided into three fractions: First, AE has colonial status and 
$\mathrm{BE}$ has dominant status. And then it influences the development of English language preferences, namely British and American English (Thomason, 2001; Crystal, 2003). When the First World War was over, AE continued itself to establish its own character, including how to state expressions, vocabulary (including being racy), diction and even more pronunciation. Even it was being underestimated because of being the second-class English, AE turns out to have same status and values with BE (Han, 2019; Bent and Holt 2017). The main point is $\mathrm{BE}$ is the ancestor of $\mathrm{AE}$ and both become two EVs with their own respective characters. Relating to the divergence between these two EVs, Qiu \& Lingyu (2010) argued that $\mathrm{BE}$ and $\mathrm{AE}$ belong to one language that is spoken by two countries.

$\mathrm{BE}$ and $\mathrm{AE}$ becomes unquestionable in the world today. The fact is many varieties attract, and raise a lot benefit, as well as a world spotlight (Dörnyei, Csizér \& Németh, 2006). The global status that clings to English results the existing linguistic variation across the globe, and due to EVs, as well as the social-culture existence underpinning how the community and its people along with its culture represent EVs. Practically, English teacher's accent may automatically affect English teaching. In short, the uprising demand of native speaker English speakers are worldwide (Lasagabaster \& Sierra, 2005).

Ryan \& Giles (1982) explained that English variety studies have abundant evidences spreading over decades and social sciences and they give essential implication to sociolinguistics discipline. Thus, sociolinguistics develops in line with many entries from social culture that function as the enrichment. Cargile (2000) said that powerful social culture may more than transfer involved referential message. It can be said also that both $\mathrm{BE}$ and $\mathrm{AE}$ are EVs that have the same origin and, within their development, they get injected by huge influence of social culture represented by their speakers. Besides, their countries, USA and UK, are separated by ocean miles away that create the differences across linguistic features on EV. However, listeners across the globe have little respond because what they need is not English as two varieties, but two varieties that are perceived as one English (Carrie, 2017). Meanwhile, Preston (2008) described that a listener may think that either BE or AE can be perceived as "educated" and "sophisticated" simply due to his or her accent presumed as 'British'. Cargile (2000) also reinforced that "such views about EV can be ambiguous within social culture context and frequently it requires social problem solving. EV characterizes substantial communicative fact to explore.

Even though $\mathrm{BE}$ and $\mathrm{AE}$ are different in phonetics, vocabulary and grammar as previously described, the natural characteristics of Linguistic features of EV still make it 
clear that both main EVs are just two varieties belonging to a language, English, not two separated languages (Mair, 2007; Moody, 2011). Along with the time changes, those characteristics of both English characteristics have also developed. In addition, the differences will stay existing (Sevinj, 2015). Thanks to the development of technology that those differences can be overcome and all EFL learners across the globe can easily understand American and British English (Yan, 2002). However, the technology development cannot keep away from the attitudes clinging to both English varieties, such as, the one is more professional and another one has financial benefit and many other stereotypes dealing with the attitude of both English varieties (Rindal 2010).

EFL learners' attitudes toward specific EV, to some certain extents, may have implication to the way they pronounce English though the linguist condemn that this is an old and unnecessary issue (Lippi-Green, R, 2012). However, the reality shows that some teachers of English discredit learners' pronunciation when they speak English with BE because the teacher is only familiar with $\mathrm{AE}$, for instance. Then it becomes a serious matter when it effects learners' English grade. Gonzalez (2004) added that teachers and learners are often excited with having ability to imitate a 'native' accent convincingly. However, it collides with their prejudice and perplexity about these EV. Somehow their attitudes are split apart.

One related study written by Carrie (2017) underlined that BE is professional and AE is urban connecting to EFL learners' attitude on EV in Spain. It also found that EFL learners' attitude on AE and BE is complex and dynamic. To understand EFL learners' attitude and EV with its functions might be potential to enrich EFL learning by designing appropriate learning materials. Another study conducted by Sevinj (2015) revealed that the attitudes of EFL learners towards English varieties indicating that accents perceived as Standard English is considered to be more prestigious competence that indicates high status. However, the present study investigates specific EV, namely $\mathrm{AE}$ and $\mathrm{BE}$, and finds out EFL learners' attitude in university level in Indonesia that are supposed to be included into syllabus making to avoid learners' prejudice and perplexity.

\section{B. Methodology}

There were 50 learners of English education program participated on this survey as respondents. They put forward their attitudes on British and American English into open ended questionnaire which contains three questions. All questionnaires were grouped into three classifications. First tendency shows the preference on American English. Second 
shows the preference on British English. Third shows no tendency at all. Each has various description and attitude of EFL learners. Last step is calculating the percentage of each tendency which leads to the formation of finding and conclusion of this survey. The data were analyzed by using SPSS

\section{Findings and Discussion}

\section{Findings}

There are questions underlying the open ended questionnaire. (1) How do you know that English has specific preferences? Mention those preferences based on your knowledge. (2) Is standardized English referred to British or American English? Mention your reason (3) Is it important for you to know the differences between British and American English? Why? (4) What is your expectation and recommendation for your lecturer of English after you know that there are specific English varieties?

On the previous explanation, the analysis of the survey is divided into three categories. The first category shows only 1 learner which means $2 \%$ of EFL learners' attitude that shows tendency to be keen on British English (Jarvella et al. 2001) as stated in the following excerpt;

Table 1. Answer from first category (one EFL learner)

\begin{tabular}{lll}
\hline \multicolumn{2}{c}{ Question } & \multicolumn{2}{c}{ Answer } \\
\hline How do you know that I've been learning English since elementary school, \\
English has specific & $\begin{array}{l}\text { continued to junior high school and senior high school until } \\
\text { preferences? }\end{array}$ \\
& now in English education program. Specifically, my \\
& English teachers and lecturers never mention and describe \\
& English variety, British and American English. However, I \\
& know the existence of specific English variety from \\
& internet. Those preferences are British, American, and \\
& Australian.
\end{tabular}

Is standardized English Surely, it is important to know British and American accent referred to British or because my teacher taught me to write 'colour' instead American English? Mention 'color'. In fact, both are correct. My teacher might have your reason. misunderstood about this.

\begin{tabular}{|c|c|}
\hline $\begin{array}{l}\text { Is it important for you to } \\
\text { know the differences } \\
\text { between British and } \\
\text { American English? Why? }\end{array}$ & $\begin{array}{l}\text { That's why I'm confused. My teachers also don't give me } \\
\text { precise answers. I've tried googling. If the blogger British, } \\
\text { they will say British English is standardized English. Vice } \\
\text { versa, when the blogger American, they say that } \\
\text { standardized English is American English. However, I } \\
\text { insist that standardized English is British because to me, }\end{array}$ \\
\hline
\end{tabular}


British English is originally from Great Britain not from America.

\begin{abstract}
What is your expectation and My recommendation for you who want to learn English, recommendation for your just apply British English because British English is lecturer of English after you professional, high prestige, and language for science and know that there are specific technology. That British English originally was born in English varieties? United Kingdom is the fact.
\end{abstract}

This learner said that British English seems to be professional (Carrie, 2017), high class, noble, unique and aesthetic (Bernaisch, 2012). Even though it's hard to understand, this learner argues that the name of English is related to the name of England, the country where English originally came from (Mompeán González, 2004). Thus, British English is the only English accent that must be academically and non-academically learned. Vice versa, the learner also argues that American English is not professional. It is urban, violent, and rough. The second category shows $50 \%$ of EFL learners don't care about those differences between American and British English as the following summary of EFL learners' attitude to the four questions;

Table 2. Answer summary from second category (25 EFL learners)

Question Answer summary

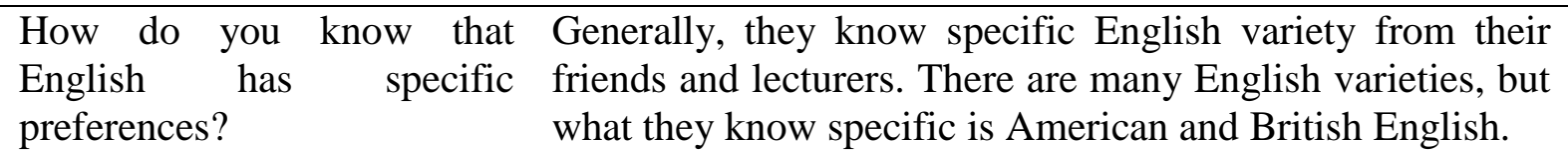

Is standardized English For them it is surely important to know and learn British referred to British or and American English but to apply one of them in speaking American English? Mention English is not needed. The most important thing if they your reason. speak English, no matter what accent they have, their listener will understand their English. They speak English, for instance, with Indonesian accent and when they talk English with their British friends, they understand and their communication ran well. So, they are not too fanatic of one of them

Is it important for you to I understand this is not easy to answer. However, I don't know the differences have too much concern about this issue. I think between British and standardized English is an academic or formal English American English? Why? which doesn't have swearing words such as, damn, bullshit, etc. In other word, standardized English is English used in formal setting like seminar, conference, speech, presentation, etc. 


\begin{abstract}
What is your expectation and Their recommendation for who want to learn English, you recommendation for your don't need to apply British English because British English lecturer of English after you is professional, high prestige, and language for science and know that there are specific technology. In addition, British English is the real ancestor English varieties? of English.
\end{abstract}

Their attitude on this issue is they will become teachers of English for Indonesian learners and they might have less chance of getting contact with native speakers of English. Thus, American or British English is the same for them. They just suggest that for those who want to visit or work in one of both countries, it is essential for them to learn one of those EVs.

The third category shows the tendency of American accent preference displaying $48 \%$ which means less than the second category (Henderson et al. 2012) and the following is conclusion of EFL learners' attitude to the four questions;

Table 3. Answer summary from third category (24 EFL learners)

Question Answer explanation

How do you know that $\begin{aligned} & \text { Coincidently, they answer that they know specific } \\ & \text { English has } \\ & \text { preferences? }\end{aligned}$
$\begin{aligned} \text { said they might not even forget how they got the } \\ \text { information about specific English variety. }\end{aligned}$

Is standardized English They said that it is important to recognize and learn BE and referred to British or $\mathrm{AE}$ as well as apply one of them in speaking English is American English? Mention needed. The most important thing in speaking English, no your reason. matter what accent we have, our listener will understand our English. I speak English with Indonesian accent and when I talk English with my British friends, they understand and our communication ran well. So, I'm not too fanatic of one of them
Is it important for you to They said standardized English must refer to American know the differences English because standardized English test is made in between British and American English such as TOEFL, IELTS, and TOEIC. In American English? Why? other word, standardized English is American English coming from USA. As we know USA is the country that has dominant position in United Nations socially, economically and politically.

\begin{tabular}{ll}
\hline What is your expectation and & Their recommendation for those who want to learn \\
recommendation for your English, just trust American English because when \\
lecturer of English after you & browsing famous gaming you tuber, they are dominantly \\
know that there are specific & American with, definitely, speaking American English. If \\
& we see creative industry like movie and music, American \\
\hline
\end{tabular}


English varieties?

creative industry is always dominant, trendsetter, and of course they use American English. In fact, American English is the most influential English.

It means that it can't be the basis that American English is more outstanding than British English. However, their interesting attitudes are revealed as follows; TOEIC, TOEFL, and IELT are constructed by American. Those standardized English tests can strengthen their paths to achieve better career (Cargile, 2000). Most virtual games are created and played by American. It means if they can speak with American English accent, they can have good income by being gaming you tuber. Furthermore, American music and movies are most liked worldwide. Its implication is they are more familiar with American English than British English. They argue that British English, particularly accent, is more complicated and heartbreaking to understand (Janicka et al. 2008). Further additional data underpinning the three categories are based on EFL learners' interest and hobbies. The learner of the third category often engages American creative industry such as gaming, YouTube, music and movies. In addition, they have prejudice on British English. They said that it's tiring to listen to or even talk with British accent, particularly the pronunciation. They said also, American English is good commodity in creative industry like gaming, music and movie world. The learner from the first category tends to have such a persistence that learning English must be based on British English because English was born in United Kingdom.

The finding of this survey indicates that EFL learners' attitudes on British and American English are various. However, most EFL learners, 50\%, don't put more attention on this issue. They don't care about other learners' prejudice and perplexity on this issue. $2 \%$ of learners persisted that British English is the best. $48 \%$ of learners have good attitude toward American English because what they mostly watch in social media comes from American social culture. The perplexity is derived from lots of things that EFL learners have to memorize starting from accent, vocabulary, spelling and grammar between British and American English.

Then the prejudice emerges when most learners have American English as their English variety model just because coincidently they watch most American social and culture over creative industry on social media and they judge BE is not standardized English. 


\section{Discussion}

From aforementioned finding, it is obvious that EFL learners in still get stuck on such a prejudice and perplexity on some differences between American English and British English. Carrie (2017) investigated that the attitudes held by EFL learners in Spain towards reference accents (American English and British English) are complex and dynamic. The investigation result showed that American English reflects urban and British English reflects professional. However, in the present study, the result shows different. EFL learners' attitude are diverse. 2\% persist that British English is one thing EFL learners are supposed to learn. 45\% said that American English is easy to understand and more accessible to earn more income. Other 53\% of EFL learners said that American and British English are all the same. Somehow, they deal with the perplexity about what on earth they are supposed to choose. In the long run, they put themselves in between.

Their perplexity then develops their own attitudes. One perceives British is a must which reflects that that student has such an idealism about English (Jarvella et al., 2001). Some said American will support their future in terms of finance which reflects that they have engaged American technology, such as YouTube, google, vlog, and Facebook as media to earn the money. Those technology definitely apply American English as the main language just like in setting, notification and many others. In gaming world, speakers from American English are more preferable because it is easy to understand, more attractive, and creating chemistry with the viewers González's (2004). That's why gaming world spoken using American English accent has most subscribers.

The following fact that supports this attitude is the existence of TOEIC, TOEFL, IELT which are standardized English tests which are made by USA. Though some major attitudes are still in ignorance, yet, what they watch, what they learn, what they list are some sources taken from American English which means that they may ignore the existence of English variety, but their attitude towards American English is 100\% supportive. These tendencies seemingly have actual data from everyday life. Thus, without any research about this issue, EFL learners are convinced with their own attitude. They said they are not native speaker of English, so they just feel free to pick up either British or American English (Spencer-Oatey 2008). They also expect their teachers and instructors apply one of those accents which is hard indeed, because being able to speak English nativelike needs real experience of at least living in the English speaking countries. Meanwhile, this survey might be the guidance for non-native English teachers for reflection. Bearing in mind, this survey is 
conducted by the writer of non-native speakers of English which means it is objective which also means the writer is not influenced by either USA or United Kingdom.

\section{Conclusion}

This investigation of the survey has shown that EFL attitude on American and British English are diverse, complex and dynamic. Then, it prompts perplexity and prejudice among EFL learners. The former came up due to no precise answer, explanation or solution toward which EV EFL learners are supposed to apply until today. The latter came up since some facts stand for each language variety, American English or British English, until today. Even though, it is not yet a precise answer for Standard English. Learners from the first category uses the sense that Standard English must take the origin where English came from. Learners from second category view that Standard English either American or British English doesn't matter. They take both EVs for granted just the way they are. They definitely welcome both varieties. Learners from the third category persist that American English bears financial benefit from the point of creative industry, social, culture, and education.

However, understanding EV and its function can be the way to enrich EFL learning by designing suitable teaching materials. It can be utilized within the classroom to achieve the instrumental goals and learning outcome. Further recommendation goes to English teachers or instructors to always set teaching material in accordance with the phenomenon of specific language variety, American - British English. So, there won't be any perplexity and prejudice among EFL learners.

\section{References}

Ahmed, Z.T., Abdullah, A.N., \& Heng, C.S. (2013). The Role of Accent and Ethnicity in the Professional and Academic Context. International Journal of Applied Linguistics \& English Literature. ISSN 2200-3592 (Print), ISSN 2200-3452 (Online). Vol. 2 No. 5; September 2013

Bent, T., \& Holt, R. F. (2017). Representation of Speech Variability. WIREs Cogn Sci. doi: $10.1002 /$ wcs. 1434

Bernaisch, T. (2012). Attitudes towards Englishes in Sri Lanka. World Englishes. 31 (3), 279291. 
Cargile, A. C. (2000). Evaluations of employment suitability: Does accent always matter. Employment counseling, 37,165-176.

Cargile, A. C., \& Giles, H. (1998). Language attitudes toward varieties of English: An American-Japanese context. Applied Communication Research, 26, 338-356.

Carrie, E. (2017). British is professional, American is urban': attitudes towards English reference accents in Spain. International Journal of Applied Linguistics. Vol. 27, No. 2,2017

Crystal \& David. (2003). A Dictionary of Linguistics and Phonetics, $3^{\text {rd }}$ ed. Cambridge: Massachusetts.

Cateford, J. C. (2003). A Practical Introduction to Phonetics. New York: Oxford University Press, pp.120- 201.

Coupland, N., \& Bishop, H. (2007). "Ideologies' Values for British Accents." Journal of Sociolinguistics.

Dimitrova, S. (2010). British and American Pronunciation. New York: Oxford University Press

Dörnyei, Z., K. Csizér, \& N. Németh (2006). Motivation, language attitudes and globalization: A Hungarian attitude. Clevedon: Multilingual Matters.

Fought, C. 2002. "California Learners' Perceptions of, You Know, Regions and Dialects?" In Handbook of Perceptual Dialectology. Vol II, edited by D. Long and D. R. Preston. Amsterdam: John Benjamins.

Garrett, P. (2009). Attitudes to Language. Cambridge: Cambridge University Press.

González, J. A. (2004). Options and criteria for the choice of an English pronunciation model in Spain. In J. Anderson, J. M. Oro, and J. Varela Zapata (eds), Linguistic attitudes from the classroom: language teaching in a multicultural Europe. Universidade de Santiago de Compostela.

Han, L. (2019). A Review of the Major Varieties of English Language. International Education Studies; Vol. 12, No. 2; 2019 ISSN 1913-9020 E-ISSN 1913-9039 Published by Canadian Center of Science and Education

Henderson, A., D. et al. (2012) The English pronunciation teaching in Europe survey: Selected results. Research in Language 10.1: 5-27.

Hos seinzadeh, N. M., Kambuziya, Z., \& Shariati, M. (2015). British and American Phonetic Variety. Journal of Language Teaching and Research. ISSN 1798-4769. Vol. 6, No. 3, pp. 647-655, May 2015 DOI: http://dx.doi.org/10.17507/j1tr.0603.23

Jarvella, R. J., E. Bang, A. L. Jakobsen, and I. M. Mees (2001). Of mouths and men: nonnative listeners' identification and evaluation of varieties of English. International Journal of Applied Linguistics 11.1: 37-56. 
Lasagabaster, D. (2005) Attitudes towards Basque, Spanish and English: an analysis of the most influential variables. Journal of Multilingual and Multicultural Development.

Lippi-Green, R. (2012) English with an accent: language, ideology and discrimination in the United States. 2nd edn. Oxford: Routledge.

Janicka, K., Kul, M., \& Weckwerth, J. (2008) Polish learners' attitudes to native English accents as models for EFL pronunciation. In K. Dziubalska-Kolaczyk, and J. Przedlacka (eds), English pronunciation models: a changing scene, 2nd edn. Hamburg: Peter Lang.

Mair, C. (2007). Varieties of English around the world: Collocational and cultural profiles 1. DOI: $10.1515 / 9783110197860.437$.

Moody, S. (2011). The diversity of English in America. Popular linguistics, 1.

McKenzie, R. M. (2015). "The Sociolinguistics of Variety Identification and Categorisation: Free Classification of Varieties of Spoken English amongst Non-Linguist Listeners." Language Awareness 24 (2).

Mesthrie, R., Jpan, S., Ana, D., \& William, L. L. (2009). Introducing sociolinguistics. Edinburgh University Press.

Preston, D. R. (2008). How can you learn a language that isn't there? In K. DziubalskaKolaczyk, and J. Przedlacka (eds), English pronunciation models: a changing scene, 2nd edn. Hamburg: Peter Lang.

Rindal, U. (2010) Constructing identity with L2: pronunciation and attitudes among Norwegian learners of English. Journal of Sociolinguistics 14.2: 240-61.

Ryan, E. B., \& Giles, H. (1982). Attitudes towards language variation: Social and applied contexts. London, England: Edward Arnold.

Roach, P. (2009). English Phonetics and Phonology: A Practical Course. Cambridge: Cambridge University Press.

Sevinj, M. (2015). American Variety of English Language. International Journal of English Linguistics. Vol. 5, No. 5; 2015 ISSN 1923-869X E-ISSN 1923-8703

Sierra, J. M. (2005). The nativeness factor: an analysis of learners' preferences. ITL International Journal of Applied Linguistics 148: 21-43.

Spencer, \& Oatey, H. (2008). Culturally speaking: culture, communication and politeness theory. London: Continuum.

Thomason, \& Grey, S. (2001). Language Contact. Edinburgh: Edinburgh University Press.

Qiu, Lingyu. (2010-12). British English VS American English. INS Eduard Fontserè: Judit Nochta Publication. 